\title{
Structure-Function Studies on N-Oxalyl-Diamino-Dicarboxylic Acids and Excitatory Amino Acid Receptors: Evidence that $\beta$-L-ODAP Is a Selective Non-NMDA Agonist
}

\author{
Richard J. Bridges, ${ }^{1}$ David R. Stevens, ${ }^{3}$ Jennifer S. Kahle, ${ }^{2}$ Peter B. Nunn, ${ }^{4}$ Munaf Kadri, ${ }^{2}$ and Carl W. Cotman ${ }^{2}$

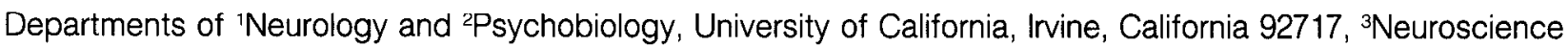 \\ Laboratory, VAMC, Brockton, Massachusetts, and 4Department of Biochemistry, King's College, London, England
}

\begin{abstract}
Excitatory amino acids and their receptors play an important role in both normal synaptic transmission and excitotoxicmediated neuronal death. In the present investigation we have prepared a series of glutamate analogs and examined the pharmacological specificity with which they interact with excitatory amino acid receptors. Included within this group of compounds is a potent excitotoxic amino acid, $\beta$ - $\mathrm{N}$-oxalyl$L-\alpha, \beta$-diaminopropionic acid ( $\beta$-L-ODAP). This excitotoxin is of particular interest because it has been identified as a major causative agent of human neurolathyrism, a disease characterized by permanent spastic paralysis. The site of action of $\beta$-L-ODAP was delineated with both electrophysiological recordings in hippocampal slices and radioligand binding assays in synaptic plasma membranes. We report that $\beta$-L-ODAP is a potent agonist at the non- $N$-methyl-Daspartate (NMDA) type of excitatory amino acid receptor. $\beta$-L-ODAP interacts most potently with the quisqualate class of non-NMDA receptors $\left(I_{50}=1.3 \mu \mathrm{M}\right)$, less potently with the kainate receptor $\left(I_{50}=17 \mu \mathrm{M}\right)$, and very weakly with NMDA receptors. The specificity of this binding was consistent with physiological experiments that demonstrated that $\beta$-L-ODAP-induced depolarizations were potently blocked by the newly identified non-NMDA receptor antagonist, CNQX, but were not affected by the NMDA antagonist D-AP5. These results extend recent studies that have focused on the contribution of NMDA receptors to excitotoxicity and highlight the potential involvement of non-NMDA receptors in excitotoxic-mediated cell death.
\end{abstract}

Over the past several years considerable attention has been focused on excitatory amino acids, their receptors, and their mutual involvement in excitotoxic-mediated cell pathology (for reviews, see Meldrum, 1985; Rothman and Olney, 1986, 1987). Excitotoxicity is currently thought to be an underlying mechanism responsible for the neuronal degeneration that is associated with a wide spectrum of neurological conditions (e.g., epilepsy, Huntington's disease, anoxia, ischemia, hypoglycemia). The majority of these studies have centered on the role of $N$-methylD-aspartate (NMDA) receptors in these processes and have demonstrated that NMDA receptor antagonists can offer some protection from the toxic action of NMDA agonists (Meldrum,

\footnotetext{
Received July 1, 1988; revised Oct. 20, 1988; accepted Oct. 21, 1988.

This work was supported in part by American Assistance Foundation Grant 11394 and NIH Grant A607918.

Correspondence should be addressed to Richard J. Bridges at the above address. Copyright (C 1989 Society for Neuroscience 0270-6474/89/062073-07\$02.00/0
}

1985; Wieloch, 1985; Rothman and Olney, 1986). This receptor, however, represents only 1 of at least 3 different excitatory amino acid receptors at which glutamate would be expected to act in vivo (for review, see Cotman and Iversen, 1987). In the present investigation, we examine the specificity of action of $\beta-N$-oxalyl$\mathrm{L}-\alpha, \beta$-diaminopropionic acid ( $\beta$-L-ODAP), a potent excitotoxic analog of L-glutamate, and report that it selectively interacts with non-NMDA receptors. In this respect, $\beta$-L-ODAP becomes of interest with regard to both its mechanism of toxicity and as a potential probe of non-NMDA receptors.

$\beta$-L-ODAP is also of particular interest because this potent nonprotein neuroexcitatory amino acid has been reported as a major causative agent in the pathogenesis of human neurolathyrism (MacDonald and Morris, 1984; Chase et al., 1985). This disease is characterized by an irreversible, nonprogressive spastic paralysis of the lower limbs and is directly associated with the excessive consumption of seeds containing the neurotoxin (e.g., Lathyrus sativus, L. clymenum, and L. cicera; for review, see Spencer and Schaumburg, 1983; Ludolph et al., 1987). Toxicological investigations have demonstrated that $\beta$-LODAP: (1) can cross the blood-brain barrier, (2) is accumulated in the CNS following intraperitoneal or intravenous administration; and (3) produces severe convulsions and neurological signs that mimic ncurolathyrism (Rao, 1978; Metah et al., 1979, 1980; Parker et al., 1979). Injection of $\beta$-L-ODAP into the lumbar cerebral spinal fluid of the rat results in permanent bilateral spasticity and striking histological damage to both gray and white matter of the spinal cord (Chase et al., 1985). Extensive neuronal damage is also observed in the retina, hypothalamus, and area postremia of immature mice given $\beta$-L-ODAP (Olney et al., 1976). Significantly, these studies demonstrated that the cytopathological damage produced by $\beta$-L-ODAP appears to be limited to the postsynaptic components of neurons and is quite similar to the pathology that is observed after the administration of excessive amounts of L-glutamate.

In their early studies characterizing excitatory amino acid, Watkins and coworkers (1966) first identified $\beta$-L-ODAP as a glutamate analog with potent excitatory effects in preparation of cat spinal cord. They further suggested a possible association between the potent agonist activity of $\beta$-L-ODAP and ncurolathyrism. Electrophysiological studies of frog spinal cord characterized $\beta$-L-ODAP as a potent agonist, and it was noted that its actions resembled those of kainate more than those of NMDA (Pearson and Nunn, 1981). Later experiments by MacDonald and Morris (1984) further ascribed the site of action of $\beta$-LODAP to non-NMDA receptors, as the $\beta$-L-ODAP-induced de- 
polarization of cultured mouse spinal neurons was not blocked by NMDA antagonist D-2-amino-5-phosphono-valerate (DAP5).

In the present investigation we have used selective radioligand binding assays with synaptic membrane preparations of adult rats for directly examining the interaction of $N$-oxalyl-diaminodicarboxylic acids with the 3 major classes of excitatory amino acid receptors. Thus, $\beta$-L-ODAP, its $\mathrm{D}$ - and $\alpha$-isomers, and several other $N$-oxalyl-diamino-dicarboxylic acid homologs have been prepared (see Fig. 1) and tested for their ability to inhibit ${ }^{3} \mathrm{H}$-AMPA ( ${ }^{3} \mathrm{H}$ - $\alpha$-amino-3-hydroxy-5-methyl-4-isoxazole propionate) binding to quisqualate (QA) receptors, ${ }^{3} \mathrm{H}$-kainate (KA) binding to kainate receptors, and ${ }^{3} \mathrm{H}$-L-glutamate binding to NMDA receptors. Electrophysiological studies were carried out in parallel with these binding assays. Extracellular and intracellular recordings were made in rat hippocampal slices exposed to $\beta$-L-ODAP in the presence and absence of excitatory amino acid antagonists. We report that $\beta$-L-ODAP is a potent glutamate agonist and a selective inhibitor of binding to non-NMDA type excitatory amino acid receptors that exhibits a substantial preference for QA-type receptors.

\section{Materials and Methods}

Materials. Male Sprague-Dawley rats (175-200 gm) were obtained from Charles River (Wilmington, MA). ${ }^{3} \mathrm{H}-\mathrm{AMPA}(27.6 \mathrm{Ci} / \mathrm{mmol}),{ }^{3} \mathrm{H}-\mathrm{KA}$ $(60 \mathrm{Ci} / \mathrm{mmol})$, and ${ }^{3} \mathrm{H}-\mathrm{L}$-glutamate $(50.9 \mathrm{Ci} / \mathrm{mmol})$ were obtained from New England Nuclear (Boston). $N$-Oxalyl-diamino-dicarboxylic acids were prepared as described below. NMDA was obtained from Tocris (Bristol, England). CNQX was generously provided by Dr. Tage Honore. Kynurenic acid, as well as the other general reagents used, were obtained from Sigma (St. Louis).

Preparation of oxalyl compounds. The $N$-oxalyl-diamino-dicarboxylic acids were synthesized by reacting the parent dibasic acid with diethyloxalate at $\mathrm{pH}$ 10-10.5 (Harrison et al., 1977). These conditions generate both $\alpha$ - and $\omega$-oxalyl products (as predicted by Leclerc and Benoiton, 1968). The products are readily separable by paper electrophoresis [Whatman 3MM paper, $\mathrm{pH} 3.0(3.7 \mathrm{ml}$ pyridine: $100 \mathrm{ml}$ glacial acetic acid diluted into 2 liters $\left.\mathrm{H}_{2} \mathrm{O}\right), 77 \mathrm{~V} \mathrm{~cm}^{-1}$ for $20 \mathrm{~min}$ ] and identifiable with $1 \%$ ninhydrin in acetone after heating at $105^{\circ} \mathrm{C}$ for $5 \mathrm{~min}$. In each case, the faster-migrating compound corresponds with the $\omega$-oxalyl derivative. The $\mathrm{L}-\alpha-, \mathrm{L}-\beta-\mathrm{ODAP}$ and $\mathrm{D}-\beta$-ODAP were isolated and characterized using the chromatographic method of Harrison et al. (1977). Details of the isolation and characterization of the oxalyl derivatives of $\alpha, \gamma$-diaminobutyric acid, ornithine, and lysine will be described elsewhere.

Synaptic plasma membrane preparation and binding assays. The synaptic plasma membranes (SPMs) were prepared as a modification (Monaghan and Cotman, 1986) of the procedure described by Cotman and Taylor (1972). Briefly, male Sprague-Dawlcy rats (200 gm) wcre dccapitated, their forebrains were rapidly removed, and the brain tissue was homogenized in $0.32 \mathrm{M}$ sucrose. Following differential centrifugation, a membrane fraction enriched in synapses, but low in myelin and mitochondria, was obtained. This membrane fraction was washed 3 times

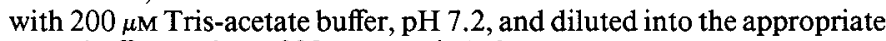
assay buffer to about $200 \mu \mathrm{g}$ protein $/ \mathrm{ml}$.

Binding to NMDA, KA, and QA receptors was quantitated with ${ }^{3} \mathrm{H}$ L-glutamate, ${ }^{3} \mathrm{H}-\mathrm{KA}$, and ${ }^{3} \mathrm{H}$-AMPA, respectively. The binding assays were carried out using optimally selective conditions of time, temperature, and buffer for each of the 3 receptor classes. ${ }^{3} \mathrm{H}-\mathrm{L}-\mathrm{glutamate}$ binding was quantitated under conditions that selectively label NMDA receptors (Monaghan and Cotman, 1986). The SPMs were incubated with ${ }^{3} \mathrm{H}$-L-glutamate $(10 \mathrm{nM}, 50.9 \mathrm{Ci} / \mathrm{mmol})$ in $50 \mathrm{~mm}$ Tris-acetate, $\mathrm{pH}$ 7.0 , at $4^{\circ} \mathrm{C}$ for $30 \mathrm{~min}$. Nonspecific binding was determined by the inclusion of $500 \mu \mathrm{M} \mathrm{L}$-glutamate. KA receptors were quantitated as previously described (Simon et al., 1976; London and Coyle, 1979). Briefly, ${ }^{3} \mathrm{H}-\mathrm{KA}(10 \mathrm{nM}, 60 \mathrm{Ci} / \mathrm{mmol})$ binding was determined in $50 \mathrm{~mm}$ Tris-citrate buffer, $\mathrm{pH} 7.0$, at $4^{\circ} \mathrm{C}$ for $30 \mathrm{~min}$. Nonspecific binding was determined by the inclusion of $100 \mu \mathrm{M}$ unlabeled KA. QA receptors were measured with ${ }^{3} \mathrm{H}-\mathrm{AMPA}$ binding as described by Honore et al. (1982). Essentially, ${ }^{3} \mathrm{H}$-AMPA $(10 \mathrm{nM}, 27.6 \mathrm{Ci} / \mathrm{mmol})$ was quantitated in $50 \mathrm{~mm}$, Tris-acetate buffer, pH 7.2, containing $100 \mathrm{~mm} \mathrm{KSCN}$ for 30 minutes at $4^{\circ} \mathrm{C}$. $\beta$-L-ODAP, or one of its derivatives, was included in the assay mixture at the indicated concentrations. Each of the assays (total volume, $1.08 \mathrm{ml}$ ) was initiated by the addition of radiolabel and terminated by centrifugation (Beckman Microfuge, top speed, $3 \mathrm{~min}$ ). The values are reported as the percentage of control (mean $\pm \mathrm{SD} ; n=$ 5-8 sets of triplicates) and have been corrected for nonspecific binding.

Electrophysiology. Electrophysiological assessment of the action of $\beta$-L-ODAP on pyramidal neurons was carried out in slices of rat (SpragueDawley) hippocampus. The slices were prepared using standard methods as previously described (Jahnsen and Laursen, 1983). Briefly, the rat was decapitated and the brain rapidly removed and placed in cold $\left(4-10^{\circ} \mathrm{C}\right)$ bicarbonate-buffered artificial cerebrospinal fluid (ACSF). The ACSF buffer contained $\mathrm{NaCl}, 127 \mathrm{mM} ; \mathrm{KCl}, 2.0 \mathrm{~mm} ; \mathrm{CaCl}_{2}, 2.0 \mathrm{~mm}$; $\mathrm{MgSO}_{4}, 2.0 \mathrm{~mm} ; \mathrm{KH}_{2} \mathrm{PO}_{4}, 1.25 \mathrm{~mm}$; $\mathrm{NaH}_{2} \mathrm{CO}_{3}, 26.0 \mathrm{~mm}$; D-glucose, $10.0 \mathrm{mM}$. The hippocampus was dissected out, and transverse $500 \mu \mathrm{m}$ sections were cut on a Vibratome. Slices of the septal third of the hippocampus were used for recording. The slices were maintained at room temperature in ACSF bubbled with $95 \% \mathrm{O}_{2} / 5 \% \mathrm{CO}_{2}$ and allowed to recover for at least $1 \mathrm{hr}$ after dissection. For recording, the slices were transferred to a recording chamber maintained at $33 \pm 1^{\circ} \mathrm{C}$, submerged and constantly superfused with bubbled ACSF.

Extracellular recording was used to examine the effect of $\beta$-L-ODAP on evoked synaptic field potentials. For these recordings, glass microelectrodes filled with $2 \mathrm{M} \mathrm{NaCl}$ (4-10 $\mathrm{M} \Omega$ resistance) were placed in the Schaffer collateral terminal zonc of the stratum radiatum of area CA1. A bipolar stimulating electrode made of 2 twisted tungsten wires was positioned in the stratum radiatum of area $\mathrm{CA} 3$ and used to stimulate the Schaffer collateral pathway. The extracellular field potentials (EFPs) were collected at a fixed latency on a sample-and-hold circuit and displayed as a continuous chart record. Digital averages of 10 EFPs were collected on an Apple II microcomputer and stored to disk for later analysis.

Intracellular recording was used to assess the action of $\beta$-L-ODAP on the membrane potential and membrane resistance. Glass microelectrodes filled with $4 \mathrm{M}$ potassium acetate with resistances of 50-80 M $\Omega$ were used to record from pyramidal neurons in the area CA. Membrane resistance was monitored by passing small $(<500 \mathrm{pA})$ square currents, $200 \mathrm{msec}$ in duration, across the membrane using the bridge circuitry of the recording amplifier. Membrane potential and the voltage transients resulting from the passage of this current were recorded on a chart recorder, and selected portions of the records were also digitized and stored to disk for later analysis.

In studies examining its action on evoked synaptic potentials and membrane properties, $\beta$-L-ODAP was dissolved in ACSF and applied to the slices as part of the superfusate. Where indicated, excitatory amino acid antagonists were applied as part of the superfusate and $\beta$-L-ODAP was applied as a drop of concentrated (1000 $\mu \mathrm{M}$ solution). Calculations based on bath volume and flow rates estimated the delivered concentration to be approximately $10 \mu \mathrm{M}$. In control experiments (data not shown), application of $\beta$-L-ODAP by either superfusion ( $10 \mu \mathrm{M})$ or dropwise $(1000 \mu \mathrm{M})$ produced similar changes in membrane conductance and potential.

\section{Results}

\section{Binding studies}

Radioligand binding assays that are selective for each of the 3 excitatory amino acid receptors provide a mechanism by which the specificity of the $\mathrm{N}$-oxalyl-diamino-dicarboxylic acids can be examined in greater detail. Therefore, these compounds were tested for their ability to block the binding of ${ }^{3} \mathrm{H}$-AMPA to QA sites, ${ }^{3} \mathrm{H}-\mathrm{KA}$ to KA sites, and ${ }^{3} \mathrm{H}$-L-glutamate to NMDA sites. The results of these experiments are reported in Table 1 as the percentage of the control binding values (i.e., $0.29 \pm 0.05 \mathrm{pmol} /$ $\mathrm{mg}$ protein for ${ }^{3} \mathrm{H}$-AMPA, $0.22 \pm 0.06 \mathrm{pmol} / \mathrm{mg}$ protein for ${ }^{3} \mathrm{H}-\mathrm{KA}$, and $0.42 \pm 0.04 \mathrm{pmol} / \mathrm{mg}$ protein of ${ }^{3} \mathrm{H}-\mathrm{L}$-glutamate at NMDA receptors). Most notably, $\beta$-L-ODAP is shown to be a potent inhibitor of the binding of radioligands to non-NMDA sites. Of those assayed, the QA receptors were found to be the most sensitive. At a concentration of $1 \mu \mathrm{M}, \beta$-L-ODAP inhibited about half of the ${ }^{3} \mathrm{H}$-AMPA binding to QA sites with little or 


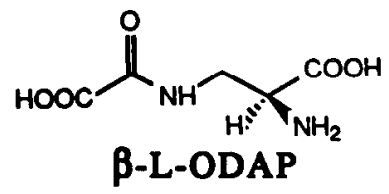

( $\beta$-N-Oxalyl-L- $\alpha, \beta$-diaminopropionic acid)<smiles>O=C(O)N[C@H](NC(=O)C(=O)O)C(=O)O</smiles>

$(\alpha-N-O x a l y l-L-\alpha, \beta$-diaminopropionic acid)

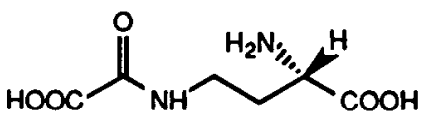 \\ $\gamma$-L-ODAB \\ $(\gamma-N-O x a l y l-L-\alpha, \gamma$-diamino- \\ butyric acid)
}

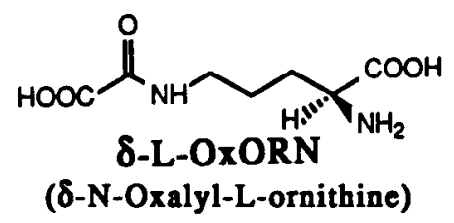

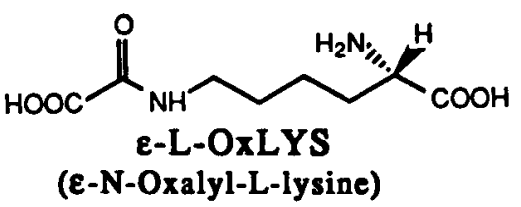

Figure 1. Structures of the $N$-oxalyldiamino-dicarboxylic acids. The homologous series of $\mathrm{N}$-oxalyl-diamino-dicarboxylic acid illustrated were prepared and tested for their ability to inhibit binding to excitatory amino acid receptors. Although both D- and L-isomers of the compounds were prepared and tested, only the L-isomers are depicted. no inhibition of binding to the other 2 receptors. Increasing the concentration of $\beta$-L-ODAP to $20 \mu \mathrm{M}$ blocked more than $90 \%$ of the ${ }^{3} \mathrm{H}$-AMPA binding, about $50 \%$ of the ${ }^{3} \mathrm{H}-\mathrm{KA}$ binding, and only $14 \%$ of ${ }^{3} \mathrm{H}$-L-glutamate binding to NMDA sites. Thus, these binding studies directly demonstrate the interaction of $\beta$-LODAP with QA and KA receptors and support the non-NMDA specificity suggested by the earlier electrophysiological experiments (MacDonald and Morris, 1984).

The inhibition of ${ }^{3} \mathrm{H}-\mathrm{AMPA}$ and ${ }^{3} \mathrm{H}-\mathrm{KA}$ binding by $\beta$-L-ODAP was also stereospecific, as little inhibition was exhibited by $\beta$-DODAP. Furthermore, the $\alpha$-isomer of L-ODAP exhibited little or no inhibition of binding to any of the excitatory amino acid receptors. This isomer was of particular interest because it can be isolated from the same seeds as $\beta$-L-ODAP and is also formed from $\beta$-L-ODAP, by rearrangement, during preparation of the seeds for consumption (Wu et al., 1976; Chase et al., 1985). The inability of $\alpha$-L-ODAP to inhibit the binding to any of the excitatory amino acid receptors is consistent with toxicology experiments that demonstrated that the $\alpha$-L-isomer was neither excitatory nor toxic.

To further characterize the apparent selectivity of $\beta$-L-ODAP binding, the concentration dependence of the inhibition of ${ }^{3} \mathrm{H}-$ AMPA and ${ }^{3} \mathrm{H}-\mathrm{KA}$ binding was examined (see Fig. 2). The doseresponse curves from these assays demonstrated that $\beta$-L-ODAP is a substantially more potent inhibitor of ${ }^{3} \mathrm{H}$-AMPA binding than ${ }^{3} \mathrm{H}-\mathrm{KA}$ binding. $\mathrm{IC}_{50}$ values were calculated and found to be about 15 -fold different: $1.3 \pm 0.2 \mu \mathrm{M}$ for inhibition of ${ }^{3} \mathrm{H}$ AMPA (10 nM) binding and $17.0 \pm 2.0 \mu \mathrm{M}$ for inhibition of ${ }^{3} \mathrm{H}-\mathrm{KA}(10 \mathrm{nM})$ binding. Calculations of apparent Hill coefficients (plots not shown) for both of these binding sites were found to be less than 1 (for AMPA: $n_{\text {app }}=0.7$, for KA: $n_{\text {app }}=$ 0.5 ). This finding is consistent with previous studies and suggests that at the radioligand concentration used $(10 \mathrm{nM})$, the observed binding would include not only high-affinity KA and QA binding sites, but also a contribution from low-affinity sites (Foster and Fagg, 1984; Honore and Neilsen, 1985; Monaghan et al., 1985).

The 1, 2, and 3 higher carbon homologs of $\beta$-L-ODAP that were prepared exhibited little or no inhibition of either ${ }^{3} \mathrm{H}$ -
AMPA or ${ }^{3} \mathrm{H}-\mathrm{KA}$ binding and only moderate inhibition of ${ }^{3} \mathrm{H}-$ L-glutamate binding to NMDA sites (Table 1). The most potent of those compounds that blocked NMDA receptor binding were $\mathrm{D}$ - and L-isomers of $\gamma$ - $N$-oxalyl- $\alpha, \gamma$-diaminobutyric acid $(\gamma$-Dand $\gamma$-L-ODAB), $\delta$ - $N$-oxalyl-D-ornithine ( $\delta$-D-OxORN), and $\epsilon-N$ oxalyl-D-lysine ( $\epsilon$-D-OxLYS). Interestingly, the $D$-isomers of the higher homologs were generally more potent inhibitors of ${ }^{3} \mathrm{H}-$ L-glutamate binding to NMDA sites than the corresponding L-isomer. This stereospecificity appears to be analogous to that demonstrated by both NMDA itself and the preferential inhibition of its receptor by the $\mathrm{D}$-isomers of the phosphonic acid antagonists (D-AP5 and D-AP7; see Watkins and Olverman, 1987).

Table 1. Pharmacological specificity of $N$-oxalyl-diaminodicarboxylic acids

\begin{tabular}{|c|c|c|c|}
\hline $\begin{array}{l}\text { Compound } \\
\text { (conc.) }\end{array}$ & $\begin{array}{l}\text { QA site } \\
{ }^{3} \mathrm{H} \text {-AMPA } \\
\text { (\% control) }\end{array}$ & $\begin{array}{l}\text { KA site } \\
{ }^{3} \mathrm{H}-\mathrm{KA} \\
(\% \text { control) } \\
\end{array}$ & $\begin{array}{l}\text { NMDA site } \\
{ }^{3} \mathrm{H} \text {-GLU } \\
(\% \text { control) }\end{array}$ \\
\hline $\begin{array}{l}\text { Control } \\
\beta \text {-L-ODAP }\end{array}$ & 100 & 100 & 100 \\
\hline $1 \mu \mathrm{M}$ & $57 \pm 5$ & $97 \pm 7$ & $96 \pm 8$ \\
\hline $20 \mu \mathrm{M}$ & $8 \pm 2$ & $56 \pm 4$ & $86 \pm 3$ \\
\hline $100 \mu \mathrm{M}$ & $0 \pm 1$ & $29 \pm 6$ & $61 \pm 9$ \\
\hline$\beta$-D-ODAP,$\quad 100 \mu \mathrm{M}$ & $91 \pm 8$ & $87 \pm 5$ & $52 \pm 6$ \\
\hline$\alpha$-L-ODAP,$\quad 100 \mu \mathrm{M}$ & $90 \pm 8$ & $97 \pm 7$ & $83 \pm 10$ \\
\hline$\gamma$-L-ODAB, $\quad 100 \mu \mathrm{M}$ & $83 \pm 8$ & $84 \pm 9$ & $36 \pm 4$ \\
\hline$\gamma$-D-ODAB, $100 \mu \mathrm{M}$ & $95 \pm 7$ & $96 \pm 9$ & $40 \pm 4$ \\
\hline$\delta$-L-OxORN, $100 \mu \mathrm{M}$ & $90 \pm 11$ & $94 \pm 7$ & $56 \pm 4$ \\
\hline$\delta$-D-OxORN, $100 \mu \mathrm{M}$ & $104 \pm 7$ & $92 \pm 3$ & $36 \pm 4$ \\
\hline$\epsilon-L-O x L Y S, \quad 100 \mu \mathrm{M}$ & $80 \pm 9$ & $89 \pm 9$ & $77 \pm 8$ \\
\hline$\epsilon-\mathrm{D}-\mathrm{OxLYS}, 100 \mu \mathrm{M}$ & $83 \pm 10$ & $98 \pm 2$ & $41 \pm 5$ \\
\hline
\end{tabular}

Inhibition of radioligand binding to synaptic plasma membrane excitatory amino acid receptors by $N$-oxalyl-diamino-dicarboxylic acids. QA, KA, and NMDA receptors were selectively assayed with ${ }^{3} \mathrm{H}-\mathrm{AMPA}(10 \mathrm{nM}),{ }^{3} \mathrm{H}-\mathrm{KA}(10 \mathrm{nM})$, and ${ }^{3} \mathrm{H}-\mathrm{L}-\mathrm{GLU}(10 \mathrm{nM})$, respectively. Details of the assays are described in Materials and Methods. Inhibitors were included in the binding assays at the concentrations indicated. All values represent specific binding and are reported as the averages $(n=5-8)$ of the percentage of control binding \pm SD. 


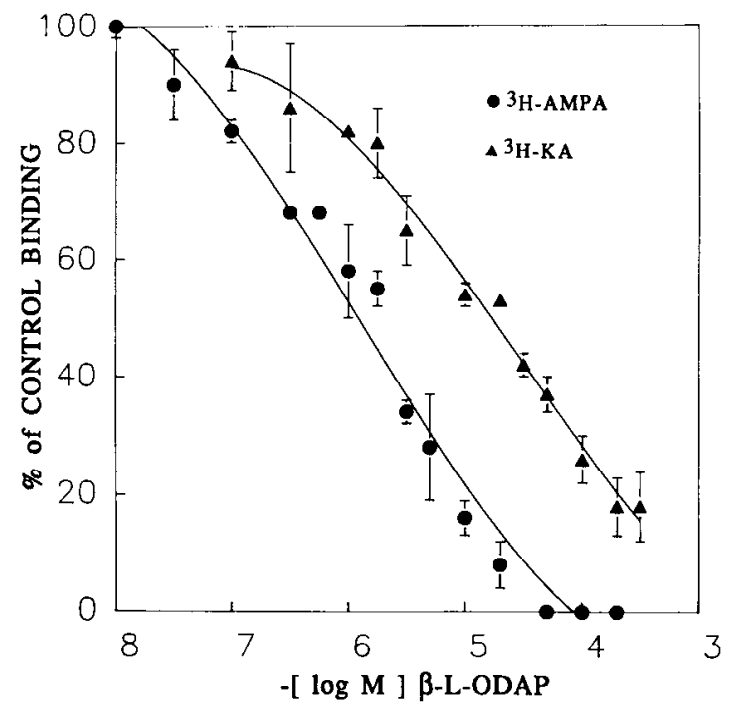

Figure 2. Inhibition of ${ }^{3} \mathrm{H}-\mathrm{AMPA}$ and ${ }^{3} \mathrm{H}-\mathrm{KA}$ binding by $\beta$-L-ODAP. Concentration dependence of the inhibition of $(0){ }^{3} \mathrm{H}-\mathrm{AMPA}(10 \mathrm{nM})$ binding to QA sites and ( $\Delta)^{3} \mathrm{H}-\mathrm{KA}(10 \mathrm{~nm})$ binding to KA sites by $\beta$-LODAP. Details of the radioligand binding assays are described in Materials and Methods. The values reported represent percentages of control binding in the presence of inhibitor (means $\pm \mathrm{SD} ; n=5-7$ ) and have been corrected for specific binding. The curves have been fitted by computer as a third-order polynomial. $\mathrm{IC}_{50}$ values were calculated to be $1.3 \pm 0.2 \mu \mathrm{M}$ for the inhibition of ${ }^{3} \mathrm{H}$-AMPA binding and $17.0 \pm$ 2.0 for the inhibition of ${ }^{3} \mathrm{H}-\mathrm{KA}$ binding.

\section{Electrophysiology}

Extracellular recordings were made of the synaptic field potentials evoked by the stimulation of the Schaffer collaterals of the rat hippocampal slice. Superfusion of $\beta$-L-ODAP produced a concentration-dependent depression of the evoked synaptic EFPs (Fig. 3). This effect occurred without a change in the amplitude of the fiber volley; therefore, it is unlikely that $\beta$-L-ODAP interfered with the propagation of the action potential. The depression of the synaptic potential was accompanied by a decrease in the threshold for the population spike that is indicative of the depolarization of neurons in the slice. The concentration dependence of the depression of the EFP by $\beta$-L-ODAP is sigmoidal, with an interpolated $\mathrm{IC}_{50}$ of $12 \mu \mathrm{M}$ (Fig. 3).

To elucidate further the mechanism by which $\beta$-L-ODAP suppressed the synaptic potential we examined its action on pyramidal neurons using intracellular recording techniques. Superfusion of a hippocampal slice with $\beta$-L-ODAP, at concentrations similar to those which suppressed the EFP, led to the depolarization of the membrane potential and an increase in action potential frequency (Fig. 4A). This depolarization was associated with a decrease in membrane resistance, as indicated by a decrease in the voltage deflection that resulted from the passage of current across the membrane (Fig. $4 A$ ). The observed decrease in membrane resistance is suggestive of a non-NMDA site of action, as NMDA receptor activation has been shown to produce an apparent increase in membrane resistance (Engberg et al., 1979).

The findings from the radioligand binding studies suggested that $\beta$-L-ODAP elicited its actions through non-NMDA receptors. We addressed this in our physiological preparation by testing the ability of excitatory amino acid antagonists to block the depolarizations induced by $\beta$-L-ODAP (see Fig. $4 B$ ). Coappli-

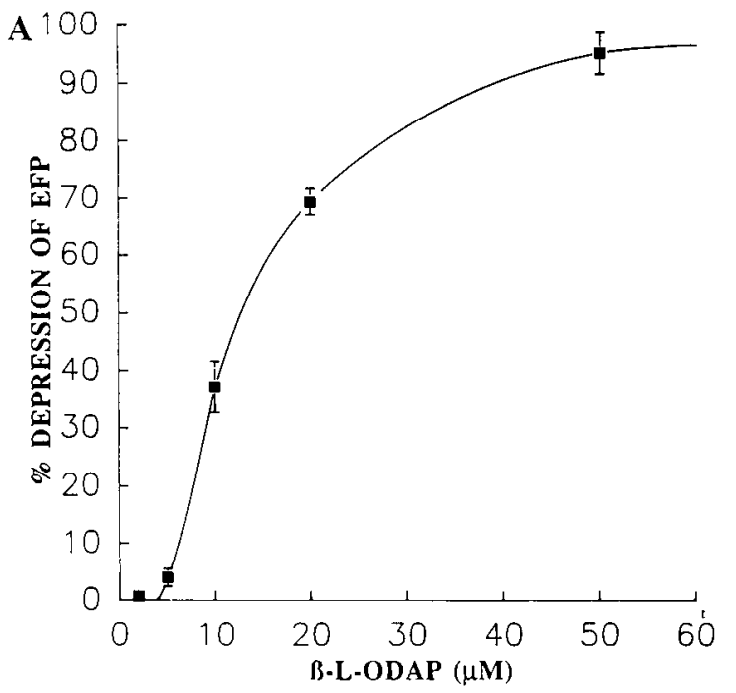

B

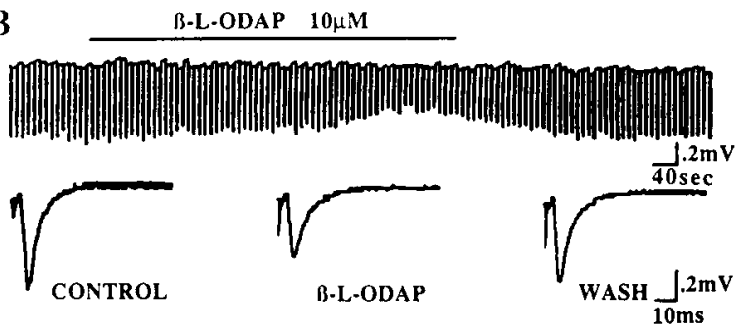

Figure 3. Extracellular records of the effect of $\beta$-L-ODAP on synaptic transmission. Application of $\beta$-L-ODAP to hippocampal slices depressed the extracellular field potential $(E F P)$ recorded in the Schaffer collateral terminal zone of area CA1. $A, \beta$-L-ODAP depresses the EFPs in a concentration-dependent manner. Each reported value represents the mean percent depression ( \pm SEM) of control EFPs $(n=3-7$ trials). The curve was fitted using a packaged cubic spline program. The $\mathrm{IC}_{30}$ value interpolated from the curve for the depression of the EFPs is 12 $\mu$ M. $B$, Representative records collected during a trial in which $\beta$-LODAP was applied at a concentration near the $\mathrm{IC}_{50}$ arc shown. A sample and hold record during the application (bar) and subsequent washout of $\beta$-L-ODAP illustrates the time course of the EFP depression. The bottom traces are averages of 10 EFPs from the record above. In the trial shown, $\beta$-L-ODAP depressed the EFP by $37 \%$.

cation of the general excitatory amino acid antagonist kynurenic acid $(500 \mu \mathrm{M})$ with $\beta$-L-ODAP depressed the induced depolarization by about $50 \%(n=3)$. Although kynurenic acid does not distinguish between NMDA and non-NMDA receptors, this result does confirm that $\beta$-L-ODAP is acting at excitatory amino acid receptors. The specific NMDA antagonist AP5, however, failed to block the effect of $\beta$-L-ODAP. This finding would be predicted from the binding data and is consistent with previous studies with cultured spinal neurons (MacDonald and Morris, 1984). The non-NMDA selectivity of $\beta$-L-ODAP was further delineated (Fig. $4, A, B$ ) by coapplication of CNQX (2,3-dihydroxy-6-cyano-7-nitroquinoxaline, also referred to as FG9065), a newly described non-NMDA antagonist (Honore et al., 1987; Blake et al., 1988). Treatment with $50 \mu \mathrm{M}$ CNQX was more effective at suppressing the depolarization induced by $\beta$-L-ODAP than was $500 \mu \mathrm{M}$ kynurenate (53 vs $37 \%$, respectively, in the neuron shown; Fig. $4 B$ ). These data are indicative of the agonist action of $\beta$-L-ODAP at the KA and QA class of excitatory amino acid receptors and are consistent with the pharmacological specificity determined in the binding studies. 


\section{Discussion}

The net result of the physiological and biochemical experiments is the demonstration that $\beta$-L-ODAP acts as an agonist at nonNMDA type glutamate receptors. This pharmacological specificity is most dramatically illustrated in the electrophysiological experiments that used the selective excitatory amino acid antagonists. Coapplications of $\beta$-L-ODAP and D-AP5, a specific NMDA antagonist, do not suppress the depolarization induced by $\beta$-L-ODAP. The depolarizing effect of $\beta$-L-ODAP is blocked, however, by the general excitatory amino acid antagonist kynurenic acid and by CNQX, a non-NMDA-selective antagonist. The direct demonstration that CNQX inhibits $\beta$-L-ODAP-induced depolarization is important, as previous studies had suggested a QA/KA pharmacology primarily on an exclusionary basis, i.e., the voltage insensitivity of $\beta$-L-ODAP-induced responses and the inability of D-AP5 to block the effect of $\beta$-LODAP (MacDonald and Morris, 1984). Significantly, CNQX has also been shown to depress synaptic transmission at nonNMDA synapses in rat hippocampal slices (Blake et al., 1988). Thus, in vivo $\beta$-L-ODAP would be expected to act at the excitatory amino acid receptors responsible for normal fast synaptic transmission (Cotman and Iversen, 1987; MacDermott and Dale, 1987).

Although CNQX proved quite useful in verifying the action of $\beta$-L-ODAP at non-NMDA receptors, the lack of antagonists that selectively discriminate between $\mathrm{KA}$ and $\mathrm{QA}$ receptors precludes the further elucidation of receptor specificity with present electrophysiological paradigms. Therefore, to delineate the action of $\beta$-L-ODAP to a greater degree, we have relied upon receptor binding studies. With selective radioligand binding assays we have demonstrated the inability of $\beta$-L-ODAP to block ${ }^{3} \mathrm{H}$-L-glutamate binding to NMDA receptors. This result is consistent with the physiological experiments, as the action of $\beta$-LODAP could not be blocked by NMDA antagonists. Furthermore, the binding assays demonstrated a preferential action of $\beta$-L-ODAP at the AMPA type non-NMDA receptors. Comparisons of $\mathrm{IC}_{50}$ values indicate about a 15 -fold more potent inhibition of the ${ }^{3} \mathrm{H}-\mathrm{AMPA}$ binding than ${ }^{3} \mathrm{H}-\mathrm{KA}$ binding. This degree of selectivity is not as great as that exhibited by AMPA and KA for their respective receptors, but is much greater than that exhibited by agonists such as glutamate or aspartate. Indeed, $\beta$-L-ODAP differentiates between QA and KA receptors to a greater extent than does $\mathrm{QA}$ itself. Comparisons of $\mathrm{IC}_{50}$ values for the inhibition of ${ }^{3} \mathrm{H}-\mathrm{AMPA}$ or ${ }^{3} \mathrm{H}-\mathrm{KA}$ binding by $\mathrm{QA}$ from previous reports indicate only a $1-5$ fold preferential inhibition of specific binding to the QA receptor (i.e., compare value reported in Foster and Fagg, 1984, vs Honore et al., 1987). In this respect, the $N$-oxalyl-diamino-dicarboxylic acid derivatives may provide some insight into the structural requirements necessary to promote non-NMDA receptor selectivity and to distinguish between the QA and KA reccptors.

The "AMPA-like" action of $\beta$-L-ODAP at QA receptors has also been suggested by preliminary experiments examining the effect of excitatory amino acids on phosphoinosotide metabolism. Previous studies by Nicoletti et al. (1986) have demonstrated that the excitatory amino acid receptors may be coupled to this second-messenger system. In recent experiments we have shown that QA produced substantial increases (15-fold) in phosphoinositol (PI) metabolism in rat brain slices (Palmer et al., 1988). Surprisingly, this increase was greater than that produced by AMPA, suggesting that QA is modulating PI metabolism at

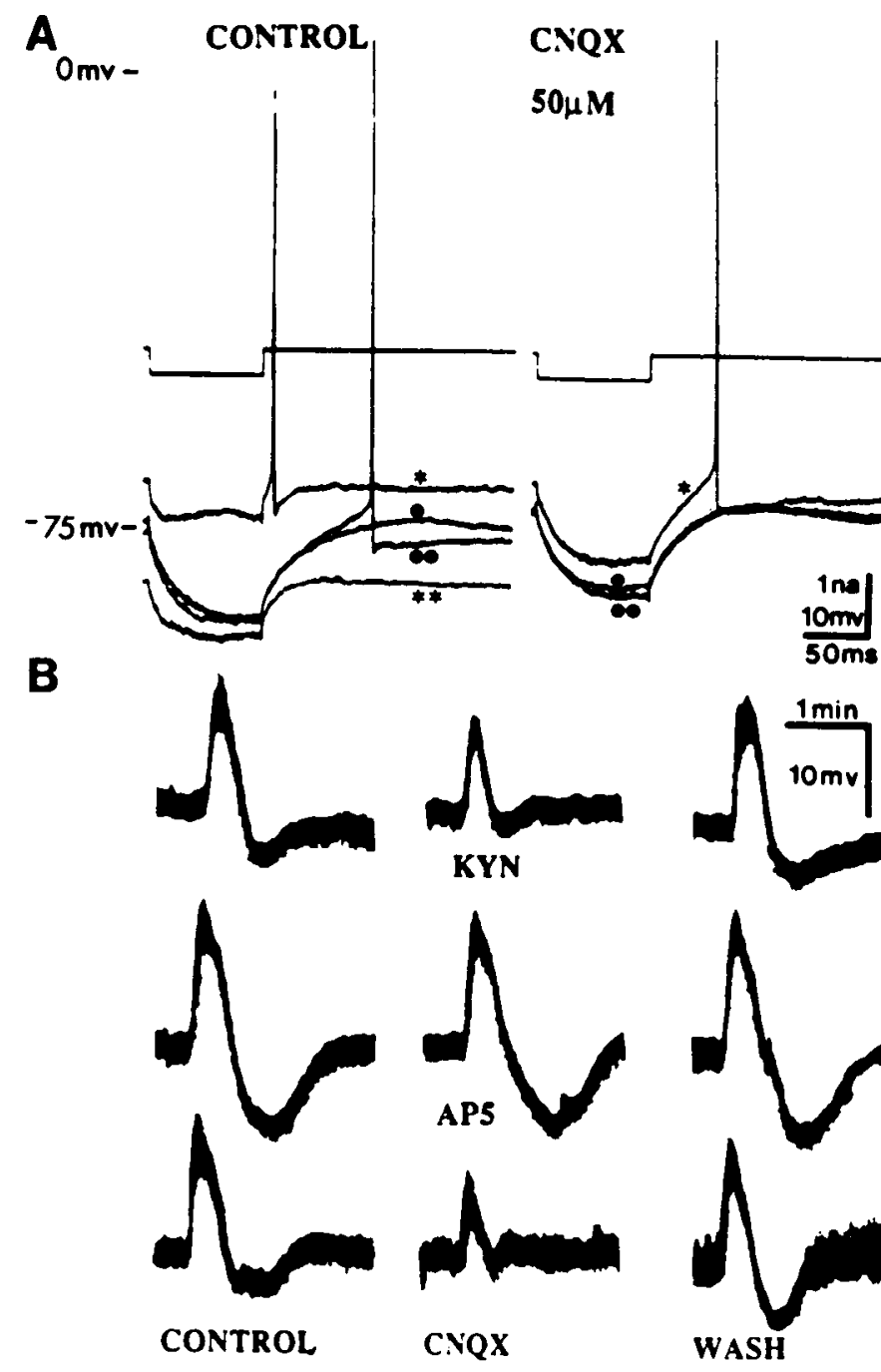

Figure 4. $\quad \beta$-L-ODAP-induced depolarization of hippocampal neurons is blocked by non-NMDA antagonists. $A$, Dropwise application of a concentrated solution $(1000 \mu \mathrm{M}) \beta$-L-ODAP to hippocampal pyramidal neurons results in depolarization that is accompanied by a large decrease in membrane resistance $(\star)$. The control trace $(\bullet)$ demonstrates the original membrane potential and input resistance. Following $\beta$-L-ODAP application there was a period of hyperpolarization that was also associated with a conductance increase $(\star \star \star)$ prior to recovery (C). Addition of CNQX $(50 \mu \mathrm{M})$ to the ACSF reduced the conductance increase produced by $\beta$-L-ODAP by $60 \%(n=2)$. Current traces are shown in the upper portion of figure. $B$, Records of membrane potentials from the same neuron demonstrate the effects of (1) a nonselective glutamate receptor antagonist, kynurenic acid $(K Y N, 500 \mu \mathrm{M}) ;(2)$ a selective NMD $\Lambda$ antagonist, AP5 (50 $\mu \mathrm{M})$; and (3) a non-NMDA antagonist, CNQX $(50 \mu \mathrm{M})$, on the depolarization induced by the drop application of $\beta$-L-ODAP (estimated concentration, $10 \mu \mathrm{M}$ ). In the records shown above, KYN and CNQX depressed the $\beta$-L-ODAP-induced depolarization by 37 and $53 \%$, respectively. Membrane potentials returned to normal after each of the drugs was washed out.

a glutamate receptor distinct from the QA receptor involved in fast synaptic transmission. Interestingly, when $\beta$-L-ODAP was tested in this paradigm, it was found to mimic the actions of AMPA and not QA (i.e., PI metabolism was increased only 2 -fold by $\beta$-L-ODAP as compared with a 15 -fold stimulation by QA). These findings further substantiate the specificity with which $\beta$-L-ODAP interacts with QA receptors and identifies it as a potentially useful compound in the study of these receptors. 
The high degree of receptor/ligand specificity of the nonNMDA receptors is illustrated by the lack of inhibition of either AMPA or KA binding by several closely related analogs of $\beta-\mathbf{L}-$ ODAP. For example, little, if any, inhibition was observed with either the $\beta$-D- or the $\alpha$-L-isomers of $\beta$-L-ODAP (Table 1). This binding specificity is also consistent with the toxicology studies that identified the $\beta$-L as the toxic isomer, even though other isomers may be present in preparations of the seeds containing the toxin (Wu et al., 1976; MacDonald and Morris, 1984; Chase et al., 1985). Interestingly, other investigators have also identified $\gamma$-ODAB in extracts from some of the same seed types that contain $\beta$-L-ODAP. (Bell and O'Donovan, 1966). The demonstration that $\mathrm{L}-$ and $\mathrm{D}-\gamma$-ODAB can block the binding of ${ }^{3} \mathrm{H}-$ L-glutamate to NMDA receptors (Table 1) is consistent with previous studies that identified both enantiomers of $\gamma$-ODAB as NMDA antagonists (Evans et al., 1982).

The pharmacological specificities reported here indicate that at exposures to low concentrations of $\beta$-L-ODAP the QA type receptor would be predicted to be most sensitive and is probably the initial receptor involved in the ensuing excitotoxic mechanisms. Continued exposure would result in higher concentrations of the toxin that would eventually interact with KA receptors. As recent attention has been focused on NMDAreceptor-mediated excitotoxicity, the present studies highlight the possible involvement of $\mathrm{QA}$ and $\mathrm{KA}$ receptors in such schemes and raise some interesting mechanistic questions. For example, current models of NMDA excitotoxicity attribute neuronal degeneration to both osmotic changes and excessive calcium influx (Rothman and Olney, 1987). In particular, the calcium-mediated damage has been shown to be reduced by noncompetitive inhibitors of NMDA receptors that block the entry of calcium through the ion channel associated with this receptor (Kemp et al., 1987). It will be of interest to determine whether similar biochemical mechanisms (i.e., calcium entry through channels not associated with the NMDA receptors) underlie QA/KA-mediated excitotoxicity.

The potential involvement of multiple receptors in excitotoxic processes also raises intriguing questions regarding the additive or synergistic action of selective excitotoxins. Perhaps combinations of selective agonists, which would essentially be equivalent to the application of excessive amounts of L-glutamate, may prove to bc morc toxic than agonists that act at only one type of receptor. The finding that normal excitatory transmission apparently depends upon the interactive function of both NMDA and non-NMDA receptors (see Cotman and Iversen, 1987; Cotman et al., 1988) also suggests that a non-NMDA agonist, such as $\beta$-L-ODAP, might not be initially toxic, but could render a neuron more susceptible to NMDA excitotoxicity. The present findings indicate that $\beta$-L-ODAP will be useful as a probe of these non-NMDA mechanisms, and they further suggest that future therapeutic strategies attempting to block excitotoxic damage must also take into account the contribution of non-NMDA receptors to the pathologies.

\section{References}

Bell, E. A., and J. P. O'Donovan (1966) The isolation of $\alpha$-and $\gamma$-oxalyl derivatives of $\alpha, \gamma$-diaminobutyric acid from seeds of Lathyrus latifolius, and the detection of the $\alpha$-oxalyl isomer of the neurotoxin $\alpha$-amino- $\beta$-oxalyl-aminopropionic acid which occurs together with the neurotoxin in this and other species. Phytochemistry 5: 12111219.

Blake, J. F., M. W. Brown, and G. L. Collingridge (1988) CNQX blocks acidic amino acid depolarizations and synaptic components mediated by non-NMDA receptors in rat hippocampal slices. Neurosci. Lett. 89: 182-186.

Chase, R. A., S. Pearson, P. B. Nunn, and P. L. Lantos (1985) Comparative toxicities of $\alpha$ - and $\beta-N$-oxalyl-L- $\alpha, \beta$-diaminopropionic acid to rat spinal cord. Neurosci. Lett. 55: 89-94.

Cotman, C. W., and L. Iversen (1987) Excitatory amino acids in the brain-focus on NMDA receptors. Trends Neurosci. 10: 263-265.

Cotman, C. W., and D. Taylor (1972) Isolation and structural studies on synaptic complexes from rat brain. J. Cell Biol. 55: 707-711.

Cotman, C. W., D. T. Monaghan, and A. H. Ganong (1988) Excitatory amino acid neurotransmission: NMD $\Lambda$ receptors and Hebb-type synaptic plasticity. Annu. Rev. Neurosci. 11: 61-80.

Engberg, I., J. A. Flatman, and J. D. C. Lambert (1979) The actions of excitatory amino acids on motor neurones in the feline spinal cord. J. Physiol. (Lond.) 288: 227-261.

Evans, R. H., P. B. Nunn, and S. Pearson (1982) $\gamma$ - $N$-Oxalyl-L- $\alpha, \gamma-$ diaminobutyrate ( $\gamma$-L-ODAB), a naturally occurring $N$-methyl-D-aspartate (NMDA) antagonist. J. Physiol. (Lond.) 327: 81P.

Foster, A. C., and G. E. Fagg (1984) Acidic amino acid binding sites in mammalian neuronal membranes: Their characteristics and relationship to synaptic receptors. Brain Res. Rev. 7: 103-164.

Harrison, F. L., P. B. Nunn, and R. R. Hill (1977) Synthesis of $\alpha$ - and $\beta$ - $N$-oxalyl-L- $\alpha, \beta$-diaminopropionic acids and their isolation from seeds of Lathyrus sativus. Phytochemistry 16: 1211-1215.

Honore, T., and M. Neilsen (1985) Complex structure of quisqualatesensitive glutamate receptors in rat cortex. Neurosci. Lett. 54: 27-32.

Honore, T., J. Lauridsen, and P. Krogsgaard-Larsen (1982) The binding of ${ }^{3} \mathrm{H}$-AMPA, a structural analogue of glutamic acid, to rat brain membranes. J. Neurochem. 38: 173-178.

Honore, T., S. D. Davies, J. Drejer, E. J. Fletcher, P. Jacobsen, D. Lodge, and F. E. Nielsen (1987) Potent and competitive antagonism at non-NMDA receptors by FG9041 and FG9065. Soc. Neurosci. Abstr. 13: 383 .

Jahnsen, H., and Laursen, A. M. (1983) Brain slice. In Current Methods in Cellular Neurobiology, Vol. 3: Electrophysiological and Optical Recording Techniques, J. L. Barker and J. F. McKelvy, eds., pp. 189224, Wiley, New York.

Kemp, J. A., A. C. Foster, and E. H. F. Wong (1987) Non-competitive antagonists of excitatory amino acid receptors. Trends Neurosci. 10 . 294-299.

Leclerc, J., and L. Benoiton (1968) On the selectivity of acylation of unprotected diamino acids. Can. J. Chem. 46: 1047-1051.

London, E. D., and J. T. Coyle (1979) Specific binding of ${ }^{3} \mathrm{H}-$ kainic acid receptor site in rat brain. Mol. Pharmacol. 15: 492-505.

Ludolph, A. C., J. Hugon, M. P. Dwivedi, H. H. Schaumburg, and P. S. Spencer (1987) Studies on the aetiology and pathogenesis of motor neuron diseases. Brain 110: 149-165.

MacDermott, A. B., and N. Dale (1987) Receptors, ion channels and synaptic potentials underlying the integrative actions of excitatory amino acids. Trends Neurosci. 10: 280-284.

MacDonald, J. F., and M. E. Morris (1984) Lathyrus excitotoxin Mechanism of neural excitation by L-2-oxalylamino-3- and L-3-oxalylamino-2-aminopropionic acid. Exp. Brain Res. 57: 158-166.

Meldrum, B. (1985) Possible applications of antagonists of excitatory amino acid transmitters. Clin. Sci. 68: 113-122.

Metah, T., N. S. Zarghami, A. J. Parker, P. K. Cusick, and B. E. Haskell (1979) Neurotoxicity of orally or intraperitoneally administered L-3oxalylamino-2-aminopropionic acid in the mouse. Toxicol. Appl. Pharmacol. 48: $1-9$.

Metah, T., A. J. Parker, P. K. Cusick, N. S. Zarghami, and B. E. Haskell (1980) The Lathyrus sativus neurotoxin: Evidence of selective retention in monkey tissue. Toxicol. Appl. Pharmacol. 52: 54-61.

Monaghan, D. T., and C. W. Cotman (1986) Identification and properties of NMDA receptors in rat brain synaptic plasma membranes. Proc. Natl. Acad. Sci. USA 83: 7532-7536.

Monaghan, D. T., L. Nguyen, and C. W. Cotman (1985) The distribution of ${ }^{3} \mathrm{H}$-kainate sites in primate hippocampus is similar to the distribution of both $\mathrm{Ca}^{2+}$-sensitive and $\mathrm{Ca}^{2+}$-insensitive ${ }^{3} \mathrm{H}$-kainate binding sites in rat hippocampus. Neurochem. Res. 11: 1073-1082.

Nicoletti, F., J. L. Meek, M. J. Iadarola, D. M. Chuang, B. L. Roth, and E. Costa (1986) Coupling of inositol phospholipid metabolism with excitatory amino acid recognition sites in the rat hippocampus. J. Neurochem. 45: 40-46.

Olney, J. W., C. N. Misra, and V. Rhee (1976) Brain and retinal 
damage from the lathyrus excitotoxin, L-3-oxalylamino-2-aminopropionic acid. Nature 264: 659-661.

Palmer, E., D. T. Monaghan, and C. W. Cotman (1988) Glutamate receptors and phosphoinositide metabolism: Stimulation via quisqualate receptors is inhibited by N-methyl-D-aspartate receptor activation. Mol. Brain Res. 4: 161-165.

Parker, A. J., T. Metah, N. S. Zarghami, P. K. Cusick, and B. E. Haskell (1979) Acute neurotoxicity of the Lathyrus sativus neurotoxin, L-3oxalylamino-2-aminopropionic acid in the squirrel monkey. Toxicol. Appl. Pharmacol. 47: 135-143.

Pearson, S., and P. B. Nunn (1981) The neurolathyrogen, $\beta$-N-oxalyl$\mathrm{L}-\alpha, \beta$-diaminopropionic acid, is a potent agonist at "glutamate preferring" receptors in the frog spinal cord. Brain Res. 206: 178-182.

Rao, S. L. N. (1978) Entry of $\beta$-N-oxalyl-L- $\alpha, \beta$-diaminopropionic acid, the Lathyrus sativus neurotoxin into the central nervous system of the adult rat, chick, and the rhesus monkey. J. Neurochem. 30 : $1467-1470$.

Rothman, S. M., and J. W. Olney (1986) Glutamate and the pathology of hypoxic/ischemic brain damage. Ann. Neurol. 19: 105.
Rothman, S. M., and J. W. Olney (1987) Excitotoxicity and the NMDA receptor. Trends Neurosci. 10: 299-302.

Simon, J. R., J. F. Contrera, and M. J. Kuhar (1976) Binding of ${ }^{3} \mathrm{H}$ kainic acid, an analogue of L-glutamate, to rat brain membranes. J. Neurochem. 26: 141-147.

Spencer, P. S., and H. H. Schaumburg (1983) Lathyrism: A neurotoxic disease. Neurobehav. Toxicol. Tetratol. 5: 625-629.

Watkins, J. C., and H. J. Olverman (1987) Agonists and antagonists for excitatory amino acid receptors. Trends Neurosci. 10: 265-273.

Watkins, J. C., D. R. Curtis, and T. J. Biscoe (1966) Central effects of $\beta$-N-oxalyl- $\alpha, \beta$-diaminopropionic acid and other Lathyrus factors. Nature 211: 637.

Wieloch, T. (1985) Hypo-glycemia-induced neuronal damage prevented by an N-methyl-D-aspartate antagonist. Science 230:681.

Wu, G., S. B. Bowlus, K. S. Kim, and B. E. Haskell (1976) L-2oxalylamino-3-aminopropionic acid, an isomer of Lathyrus sativus neurotoxin. Phytochemistry 15: 1257-1259. 